\title{
Effects of duloxetine, fluoxetine and pregabalin on fentanyl-induced hyperalgesia in rattus novergicus
}

\author{
Efeitos da duloxetina, fluoxetina e pregabalina sobre a hiperalgesia induzida por fentanil em \\ rattus novergicus
}

Oscar César Pires ${ }^{1}$, Maria Luiza Dalcim¹, Ana Luiza Montes Pigozzi ${ }^{1}$, Fabiana Mara Scarpelli de Lima Alvarenga Caldeira ${ }^{1}$, Marta Helena Rovani Pires ${ }^{1}$, Lafayette de Almeida Neto ${ }^{1}$, Irimar de Paula Posso ${ }^{1}$

\section{ABSTRACT}

BACKGROUND AND OBJECTIVES: Opioids are drugs used to relieve pain, but may cause increased pain sensitivity, known as opioid-induced hyperalgesia, which adversely affects pain management. This study aimed to check if fentanyl, an opioid widely used in the clinical practice, produces hyperalgesia that can be attenuated by duloxetine, fluoxetine and pregabalin.

METHODS: Thirty male Wistar rats were divided into six groups. The animals in group 1 received $1 \mathrm{~mL}$ of $0.9 \%$ saline solution intraperitoneally (IP) and gavage; group 2 received fentanyl at a dose of $100 \mu \mathrm{g} . \mathrm{kg}^{-1} \mathrm{IP}$ and $0.9 \%$ saline solution per gavage; groups 3, 4 and 5 received fentanyl at the dose of $100 \mu \mathrm{g} \cdot \mathrm{kg}^{-1}$ IP, and gavage with duloxetine, $40 \mathrm{mg} \cdot \mathrm{kg}^{-1}$, fluoxetine, $40 \mathrm{mg} \cdot \mathrm{kg}^{-1}$ and pregabalin, $40 \mathrm{mg} \cdot \mathrm{kg}^{-1}$, respectively. Under general anesthesia with isoflurane, all animals were submitted to plantar surgical incision. The application of Von Frey filaments assessed hyperalgesia at the second hour, one, three, five and seven days after treatment.

RESULTS: Two hours after the procedure, no differences were observed between G1 and G2, although G3, G4, and G5 showed less hyperalgesia. On day one and day three, a greater hyperalgesic effect was observed in G2 when compared to G1, G3, G4 and G5. On day five, there was a hyperalgesic effect on G2, and on day seven, there were no differences among the groups. CONCLUSION: The results suggest that fentanyl induces hyperalgesia and the efficacy of duloxetine, fluoxetine, and pregabalin in reducing it.

\footnotetext{
Oscar César Pires - Dhttps://orcid.org/0000-0002-7033-0764;

Maria Luiza Dalcim - Dhttps://orcid.org/0000-0002-5942-9691;

Ana Luiza Montes Pigozzi - (Dhttps://orcid.org/0000-0001-5623-6096;

Fabiana Mara Scarpelli de Lima Alvarenga Caldeira - (Dhttps://orcid.org/0000-0001-90849822;

Marta Helena Rovani Pires - Dhttps://orcid.org/0000-0003-0592-5304;

Lafayette de Almeida Neto - (Dhttps://orcid.org/0000-0002-5449-3344;

Irimar de Paula Posso - Dhttp://orcid.org/0000-0003-0337-2531.

1. Universidade de Taubaté, Taubaté, SP, Brasil.
}

Submitted on March 06, 2019.

Accepted for publication on December 13, 2019

Conflict of interests: none - Sponsoring sources: none.

Correspondence to:

Avenida Tiradentes, 500 - Centro

12030-180 Taubaté, SP, Brasil.

E-mail: oscarpires50@gmail.com.br

(C) Sociedade Brasileira para o Estudo da Dor
Keywords: Duloxetine, Fentanyl, Fluoxetine, Hyperalgesia, Pregabalin, Rats.

\section{RESUMO}

JUSTIFICATIVA E OBJETIVOS: Opioides são fármacos utilizados para o alívio da dor, porém, podem causar aumento da sensibilidade dolorosa, denominada hiperalgesia induzida por opioides, que afeta negativamente o tratamento da dor. $\mathrm{O}$ objetivo deste estudo foi avaliar se o fentanil, opioide amplamente utilizado na prática clínica, produz hiperalgesia que pode ser atenuada pela duloxetina, fluoxetina e pregabalina.

MÉTODOS: Trinta ratos Wistar machos, foram divididos em 6 grupos. No grupo 1, os animais receberam $1 \mathrm{~mL}$ de solução fisiológica (SF) a $0,9 \%$ por via intraperitoneal (IP) e por gavagem; no grupo 2, fentanil na dose de $100 \mu \mathrm{g} \cdot \mathrm{kg}^{-1}$ IP e SF a $0,9 \%$ por gavagem; nos grupos 3, 4 e 5 os animais receberam fentanil na dose de $100 \mu \mathrm{g} . \mathrm{kg}^{-1}$ IP e, por gavagem, receberam respectivamente duloxetina, $40 \mathrm{mg} \cdot \mathrm{kg}^{-1}$, fluoxetina, $40 \mathrm{mg} \cdot \mathrm{kg}^{-1}$ e pregabalina, $40 \mathrm{mg} \cdot \mathrm{kg}^{-1}$. A avaliação da hiperalgesia e sua atenuação foi feita pela aplicação de filamentos de Von Frey, na 2a hora e nos dias 1, 3, 5 e 7, após o tratamento.

RESULTADOS: $\mathrm{Na} 2^{\mathrm{a}}$ hora pós-procedimento não foram observadas diferenças entre G1 e G2, entretanto, G3, G4 e G5 se mostraram com menor hiperalgesia. No $1^{\circ}$ e $3^{\circ}$ dias foi observado maior efeito hiperalgésico em G2 quando comparado com G1, G3, G4 e G5. No 5 dia foi observado efeito hiperalgésico no $\mathrm{G} 2$, e no $7^{\circ}$ dia não houve diferenças entre os grupos.

CONCLUSÁO: Os resultados sugerem que o fentanil induz hiperalgesia e eficácia da duloxetina, fluoxetina e pregabalina na sua redução.

Descritores: Duloxetina, Fentanil, Fluoxetina, Hiperalgesia, Pregabalina, Ratos.

\section{INTRODUCTION}

Pain is one of the most important and complex human experiences, associated with actual or potential tissue damage, and its treatment with opioids has increased substantially in recent years, making it's prescription common in the United States ${ }^{1,2}$. However, the increase in prescriptions has been causing many problems, among which are the lack of knowledge regarding long-term efficacy, abusive use and adverse events associated with prolonged use, including opioid-induced hyperalgesia $(\mathrm{OIH})$, a 
phenomenon for which paradoxically, opioids can induce or sensitize patients to acute pain ${ }^{3,4}$. In this sense, patients who receive high doses of opioids may experience severe acute pain after surgery, with an increased dose of analgesics, and anxiety for both the patient and the physician ${ }^{4}$.

The mechanisms proposed to be responsible for $\mathrm{OIH}$ are multiple, including changes in $\mathrm{N}$-methyl-D-aspartate (NMDA) receptors and second messengers, spinal cyclooxygenase (COX) activation, the release of excitatory amino acids, reduction of inhibitory neurotransmitters, descending facilitation and the anti-analgesic system ${ }^{2,3,5,6}$.

The increased release of glutamate in the dorsal horn of the spinal cord and the consequent sustained increase in stimulus and response of NMDA receptors by removal of magnesium mediated by protein kinase-C seem to be important mechanisms involved in $\mathrm{OIH}^{7}$. These NMDA receptors can be activated by opioids, which act as excitatory neurotransmitters facilitating calcium intake into the cell and central sensitization (CS). Calcium intake causes increased protein kinase-C activity, phosphorylation, and inactivation of opioid receptors, in addition to an increase in nitric oxide synthase ${ }^{8}$.

$\mathrm{OIH}$ has been associated with an increase in cholecystokinin, a calcitonin gene-related peptide (CGRP), substance-P, and ociception in the rostral ventromedial medulla due to increased expression of excitatory opioid receptors, to the detriment of inhibitory opioid receptors ${ }^{5,9,10}$.

The descending facilitatory pathways, mediated by opioids, located in the rostral ventromedial medulla, also seem to be involved in OIH due to neuroplastic changes, since exposure to morphine causes neuroplastic changes in the rostral ventromedial medulla, with increased release of dynorphin and primary afferents fiber neurotransmitters ${ }^{3,6,11}$. In this way, the administration of opioids would cause an increase in dynorphin, which may favor $\mathrm{OIH}^{5,6}$. There is evidence that spinal dynorphin is pro-nociceptive, causing the release of excitatory neurotransmitters from primary afferent neurons, suggesting positive feedback, amplifying the sensory afferents ${ }^{6}$. In addition, prostaglandins, cytokines, and chemokines may also be relevant in the development of $\mathrm{OIH}$, since opioids activate the release of cytokines, with increased $\mathrm{C}$-fos protein in sensory neurons in the spinal cord. Other systems that may be involved in $\mathrm{OIH}$ with reduced glycinergic inhibitory control are nitric oxide synthase and heme oxygenase $e^{2,3}$.

Studies in rodents have demonstrated that fentanyl cause OIH and suggested that the protein kinase Ii $\alpha$ (CaMKII $\alpha$ ) dependent of $\mathrm{Ca}_{2}{ }^{+} / \mathrm{calmodulin}$ in the lateral capsular division of the central nucleus of the amygdala (CeLC) and the spinal cord can play a key role in the modulation of the $\mathrm{OIH}^{12,13}$.

The duloxetine, an antidepressant from the class of serotonin-norepinephrine reuptake inhibitors (SNRI), is indicated for the treatment of depressive disorder, generalized anxiety disorder, and chronic pain conditions as diabetic neuropathic pain, chronic fibromyalgia and chronic musculoskeletal pain ${ }^{14}$.

The role of serotonin and norepinephrine in the regulation of mood occurs through the ascending neuronal pathways, starting from the middle portion of the brain, extending to the limbic system and the prefrontal cortex. Besides, noradrenergic and se- rotonergic projections from the brain stem descend through the spinal cord, where it is believed to be involved in the regulation of somatosensory perception. Alterations in the serotonergic and noradrenergic pathways modify both the cerebral perception of the sensory stimuli of the ascending pathways, as well as alter the mechanism of pain inhibition by the descending pathways. Depression and chronic pain share these neuronal serotonergic and noradrenergic pathways, which is why duloxetine has been shown to be effective in these two conditions ${ }^{15}$.

Duloxetine has been shown to be effective in chronic pain conditions such as fibromyalgia, peripheral diabetic neuropathy, painful symptoms of knee osteoarthritis, and chronic low back pain. There is also evidence of relief from painful symptoms associated with depression and generalized anxiety disorder ${ }^{16}$.

The effect of fluoxetine on the serotonergic system (SRI) is well known, making evident the use of fluoxetine as a treatment option for different chronic pain conditions such as fibromyalgia, chronic tension-type headache, migraine without aura, painful diabetic neuropathy, musculoskeletal pain, chronic pelvic pain, and coronary syndrome ${ }^{17}$. Due to the effects of SRI by elevating serotonin in the central nervous system (CNS), it is postulated that duloxetine and fluoxetine may be useful in attenuating $\mathrm{OIH}$. The involvement of glutamate neurotransmission in synaptic plasticity suggests that pregabalin may also be useful in attenuating $\mathrm{OIH}^{18}$, being a GABA analog drug, which selectively binds with high affinity to the calcium channels, widely distributed in the CNS and peripheral, producing a modulating effect with a reduction of the excessive release of several excitatory neurotransmitters.

Several clinical trials have documented its effect on pain relief and quality of life, including mood and sleep disorders, and are, therefore, indicated for the treatment of fibromyalgia, neuropathic pain, and generalized anxiety disorder ${ }^{18,19}$.

Pregabalin has been shown to be effective in treating fibromyalgia, with improvement in various sleep parameters. Pain reduction was evidenced, regardless of anxiety or depression symptoms, suggesting that the pain reduction caused by pregabalin results mainly from the direct effect of the treatment, and not the indirect effect from the improvement of anxiety and depression symptoms ${ }^{20}$.

Behavioral tests such as the application of von Frey filaments and thermal hyperalgesia have been used to evaluate hyperalgesia in rats $^{21}$. In this study, the test with von Frey filaments was used to assess whether fentanyl, an opioid widely used in clinical practice, produces hyperalgesia that may suffer interference from the drugs duloxetine, fluoxetine, and pregabalin.

\section{METHODS}

For the characteristics of the animal sample and convenience, it was used 30 male Wistar rats, weighing between 220 and $300 \mathrm{~g}$, allocated in number of 5 animals per compartment, where they remained for 15 days before the beginning of the experiment for adequate adaptation, treated with balanced commercial feed and water "ad libitum," 12-hour light-dark cycle and room temperature ranging between 19 and $25^{\circ} \mathrm{C}$. 
The IASP Ethical Standards, which regulates experiments carried out in animals (Committee for Research and Ethical Issues of the IASP, 1983), were followed to conduct the experimental procedures. All experiments were carried out at the Laboratory of Pharmacology and Physiology at the University of Taubaté, SP.

To obtain mild anesthesia, the animals were placed in a $15 \times 25 \mathrm{x}-$ $15 \mathrm{~cm}$ transparent glass chamber with a transparent cover to allow the visualization of the animal, with a hole in the front and back to enable oxygen $\left(\mathrm{O}_{2}\right)$, anesthetic gases and carbon dioxide, entering and exiting, respectively. The halogenated agent used in anesthetic induction was isoflurane (Isoforine, Cristália, Itapira, Brazil), at a concentration of $4.0 \%$ in fraction of inspired oxygen $\left(\mathrm{FiO}_{2}\right)$ of 1.0 , administered by a calibrated vaporizer (Hospital $\mathrm{HB}$ ) and maintained for three minutes, time necessary for the animal to present loss of postural reflexes and inability to move in the chamber. Then, the animal was removed from the chamber and placed with the snout in a mask through which it received $4 \%$ isoflurane in $\mathrm{O}_{2}$ as in the anesthesia induction chamber.

The surgical procedure consisted of a $1.0 \mathrm{~cm}$ long, longitudinal surgical incision in the right posterior paw, according to the postoperative pain model ${ }^{21}$. This incision was made with a scalpel with blade number 11, incising the skin and the plantar fascia region of the paw, starting $0.5 \mathrm{~cm}$ from the edge of the calcaneus and extending towards the toes. Then, the plantar muscle was elevated and incised longitudinally, with its insertion intact. After hemostasis with slight pressure on the surgical area, all planes were approached and sutured with two separate stitches with 4-0 mono nylon needle thread.

The animals were randomly divided into six groups to receive similar volumes of drugs or $0.9 \%$ saline solution (SS). In group 1 , the animals received $1 \mathrm{~mL}$ of $0.9 \%$ SS by intraperitoneal (IP) and gavage; group 2 fentanyl (100 $\mu$ g. $\left.\mathrm{kg}^{-1}\right)$ (IP) in a single dose and $0.9 \%$ SS by gavage; Group 3 fentanyl $\left(100 \mu \mathrm{g} . \mathrm{kg}^{-1}\right)$ (IP) in a single dose and duloxetine $\left(40 \mathrm{mg} \cdot \mathrm{kg}^{-1}\right)$ by gavage; group 4 fentanyl $\left(100 \mu \mathrm{g} \cdot \mathrm{kg}^{-1}\right)$ (IP) in a single dose and fluoxetine ( $40 \mathrm{mg} \cdot \mathrm{kg}^{-1}$ ) by gavage and group 5 fentanyl $\left(100 \mu \mathrm{g} \cdot \mathrm{kg}^{-1}\right)(\mathrm{IP})$ in a single dose and pregabalin $\left(40 \mathrm{mg} \cdot \mathrm{kg}^{-1}\right)$ by gavage.

The evaluation of hyperalgesia was performed by applying the von Frey ${ }^{21}$ filament test. The animals were kept in a wooden chamber, with a $0.5 \mathrm{~cm}$ checkered galvanized fabric floor. A mirror was attached under the floor to allow the researcher to observe the application of the filament and the reflex of limb removal. Before applying the filament, the animals were kept in the box for about 15 minutes for adaptation. Each of the filaments, in an ascending pressure order, was applied three times in a row with an interval of 3 to 5 seconds, moving on to the next filament, being considered a positive response when the animal removed the support of the injured limb from the floor by the application of the filament. It was considered zero pressure value when the animals presented the limb fully retracted; that is, there was no need for any stimulus for the animal to collect the limb support. The collected data were recorded on a specific data collection form for each animal at the following times: $2^{\text {nd }}$ hour, $1,3,5$ and 7 days after the surgical procedure and treatment administration.

The project started after the approval by the Ethics Committee on the Use of Animals CEUA/UNITAU, under No. 03/2017.

\section{Statistical analysis}

The JMP' software from the SAS (Statistical Analysis System) Institute was used, applying the Student's $t$-test, comparing pair by pair, and adopting a significance level lower than $5 \%(\mathrm{p}<0.05)$.

\section{RESULTS}

When comparing the average weight of the animals before the beginning of the experiment, there was no statistically significant difference between groups $(p<0.05)$. In the $2^{\text {nd }}$ hour after the surgical procedure, the pain intensity, assessed by von Frey filaments, is shown in figure 1 , showing that there is no significant difference when comparing G1 with G2 ( $p=0.3759)$, but with statistical significance when they were compared to groups G3, G4, and G5 $(\mathrm{p}<0.05)$.

On the first day after the surgical procedure, the pain intensity, assessed by von Frey filaments, is shown in figure 2, showing a significant difference between G1 and G2 (p <0.05) and between these and groups G3, G4 and G5 ( $p<0.01)$.

On the third day after the surgical procedure, the pain intensity, assessed by von Frey filaments, is shown in figure 3, showing a significant difference between the G1 and G2 $(\mathrm{p}<0.05)$ and, between these and groups G3, G4 and G5 (p<0.01).

On the $5^{\text {th }}$ day after the surgical procedure, the pain intensity, assessed by von Frey filaments, is shown in figure 4, showing a significant difference between G2 and groups G1, G3, G4, and G5 $(\mathrm{p}<0.05)$.

On the $7^{\text {th }}$ day after the surgical procedure, the pain intensity, assessed by von Frey filaments, is shown in figure 5, showing a significant difference between groups.

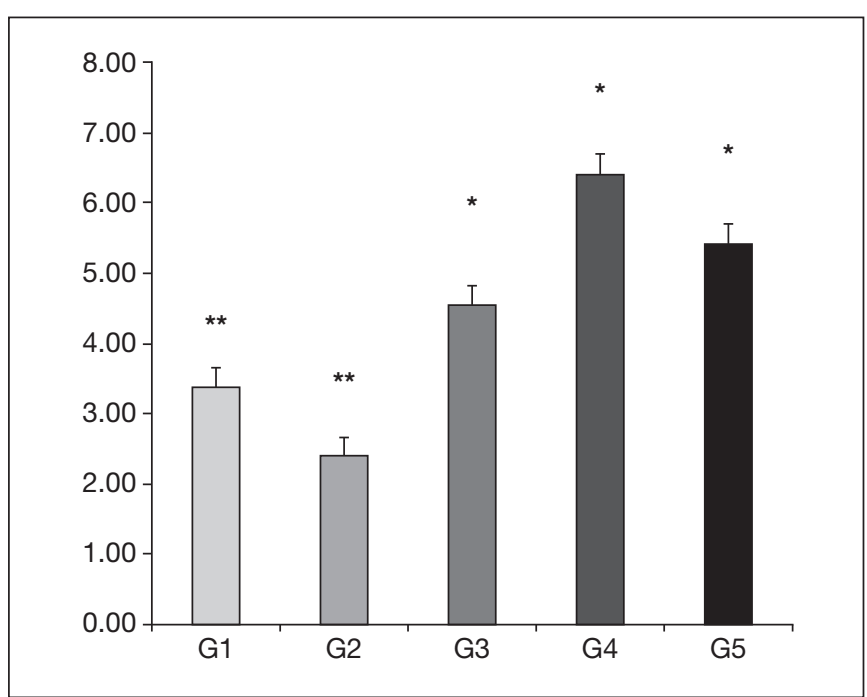

Figure 1. Student's $t$-test did not show a significant difference when comparing $\mathrm{G}^{* *}$ with $\mathrm{G} 2^{* *}(\mathrm{p}=0.3759)$, but with statistical significance when compared with $\mathrm{G} 3^{*}, \mathrm{G} 4{ }^{*}$ and $\mathrm{G} 5{ }^{*}(\mathrm{p}<0,05)$. 


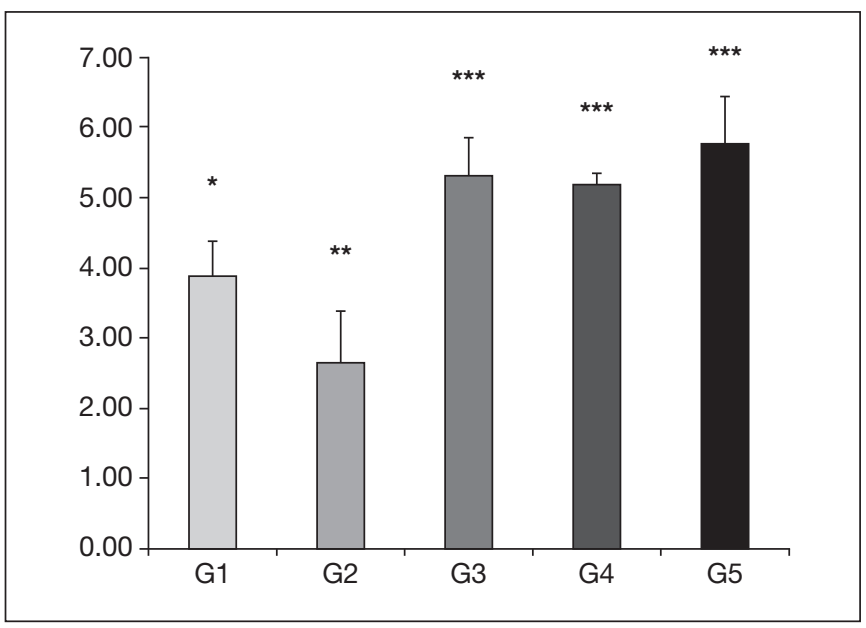

Figure 2. Student's $t$-test showed a significant difference when comparing $\mathrm{G} 1^{\star}$ with $\mathrm{G} 2^{\star \star}(\mathrm{p}<0.05)$ and with $\mathrm{G} 3^{\star \star \star}, \mathrm{G} 4^{\star \star \star}$ and $\mathrm{G} 5^{\star \star \star}(\mathrm{p}<0.01)$

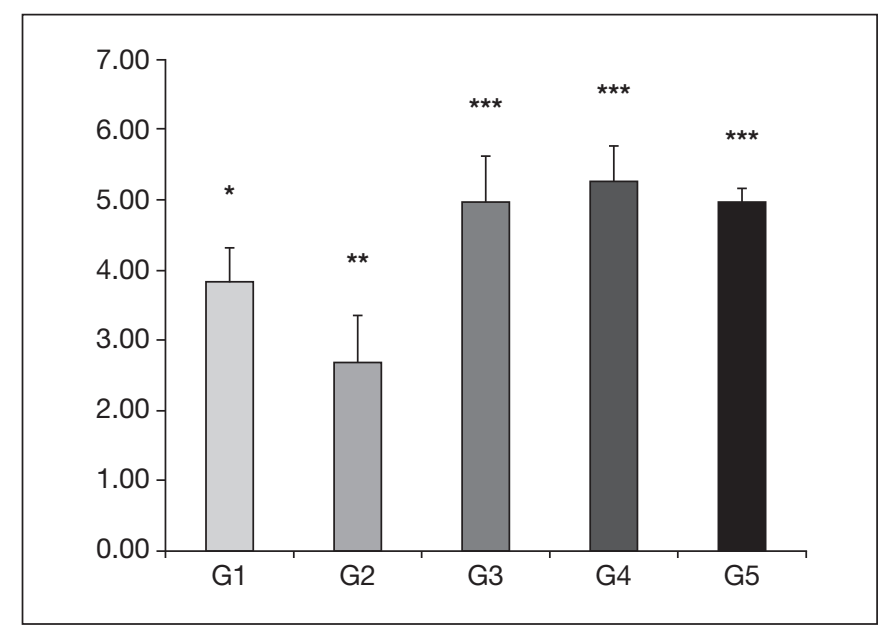

Figure 3. Student's $t$-test showed a significant difference when comparing the $\mathrm{G} 1^{\star}$ with $\mathrm{G} 2^{\star \star}(\mathrm{p}<0.05)$ and with $\mathrm{G} 3^{\star \star \star}, \mathrm{G} 4^{\star \star \star}$ and $\mathrm{G} 5^{\star \star \star}$ $(p<0.01)$

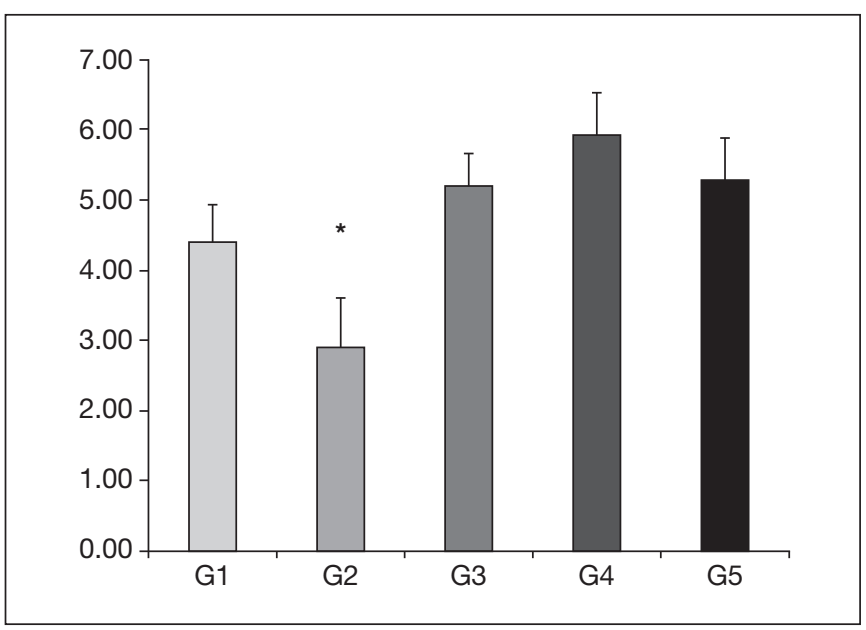

Figure 4. Student's $t$-test showed a significant difference when comparing G2* with groups G1, G3, G4, and G5 ( $p<0.05)$.

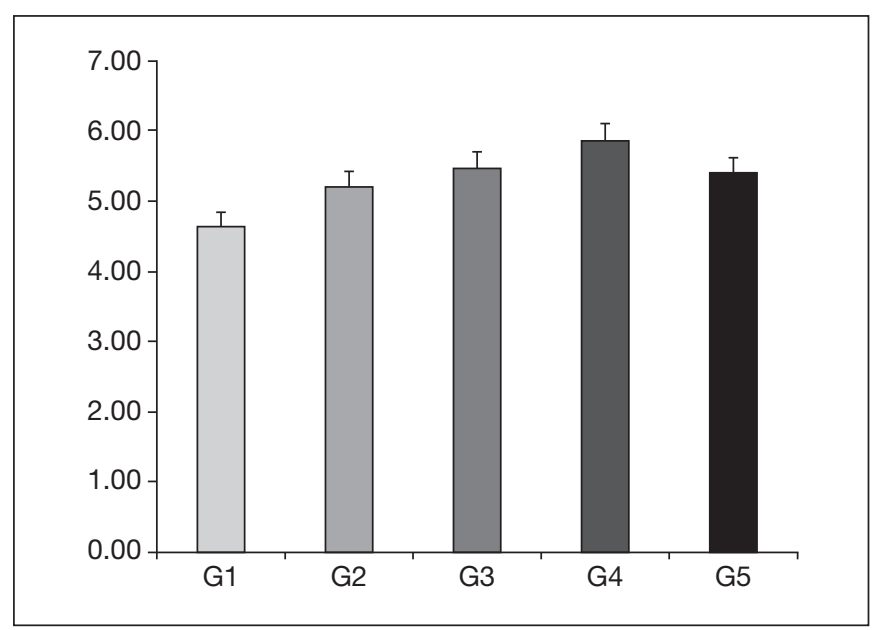

Figure 5. Student's $t$-test showed no significant differences between groups ( $p>0.05)$

\section{DISCUSSION}

Opioids are important drugs for the treatment of pain. However, at the same time that they are initially analgesic and antihyperalgesic, they can later cause hyperalgesia, making the patient more sensitive to pain ${ }^{2-5}$.

OIH has been attributed to acute desensitization of receptors by derailing $\mathrm{G}$ protein from opioid receptors, activation of NMDA receptors, among other mechanisms ${ }^{2}$.

A study has shown that the concomitant use of low doses of opioid antagonists and NMDA receptor antagonists can prevent or reduce the development of $\mathrm{OIH}$, and that ketamine in low doses can modulate $\mathrm{OIH}^{7,22,23}$.

A review proves that the mechanisms involved in the development of OIH include the glutamatergic system and NMDA receptors, spinal cyclooxygenase activation, excitatory amino acids, dynorphins, cytokines, and chemokines, prostaglandins and downward facilitation. In this sense, it is speculated that the modulation of hyperalgesia can be done with NMDA receptor antagonists, alpha- 2 adrenergic agonists, selective serotonin reuptake inhibitors, cyclooxygenase inhibitors, and GABA analogs $s^{24}$.

In accordance with the present results, a study using fentanyl in Sprague-Dawuley rats caused OIH and demonstrated a mitigating effect by the drugs duloxetine and pregabalin ${ }^{12}$.

In the present study, in the $2^{\text {nd }}$ hour after the surgical procedure, there were no differences between the control groups, which received SS by IP associated with SS by gavage compared to the group that received fentanyl by IP associated with SS by gavage. However, when comparing these with animals that received duloxetine, fluoxetine, or pregabalin, it was found less hyperalgesia, demonstrating possible involvement of serotonin and norepinephrine receptors and reduction of calcium-dependent pro-nociceptive neurotransmitters in spinal cord release, in agreement with other studies $25-27$.

When the animals were evaluated on the $1^{\text {st }}$ and $3^{\text {rd }}$ day after the surgical procedure, the group that received fentanyl via IP showed a greater hyperalgesic effect and with a statistically significant diffe- 
rence in relation to the control group, evidencing OIH. However, the group that received fentanyl via IP, in addition to showing a significant difference in relation to the control with SS, showed a difference in relation to the duloxetine, fluoxetine and pregabalin group, which were different from the control group that received SS, suggesting effectiveness in reducing $\mathrm{OIH}$.

On the $5^{\text {th }}$ day after the surgical procedure, the group that received fentanyl maintained a higher pain response when compared to the other groups. However, although G1, which received SS, showed less hyperalgesic effect compared to the fentanyl group, it did not show any difference in comparison to the groups that received duloxetine, fluoxetine or pregabalin, still showing the presence of OIH. On the $7^{\text {th }}$ day, there were no differences between the groups; that is, the possible residual effect of hyperalgesia induced by a single dose of fentanyl was not evident.

Studies using duloxetine and fluoxetine to combat pain in rodents support the results of this study that 5-HT and NE play a critical role in attenuating persistent pain mechanisms, presumably through descending modulatory pathways from pain and consequently in $\mathrm{OIH}^{28-30}$.

The use of pregabalin on nociceptive behavior and SC in a model of trigeminal pain in rats, attenuating mechanical allodynia and $\mathrm{SC}$ on the model of trigeminal pain confirms its clinical use in the treatment of pain and, although there are few studies with $\mathrm{OIH}$, there is evidence that it can be useful in controlling this type of pain ${ }^{31}$.

\section{CONCLUSION}

The present study showed evidence that fentanyl produces $\mathrm{OIH}$ and is likely to have a mitigating effect mediated by serotonin and norepinephrine and by calcium channel blockage by the drugs duloxetine, fluoxetine, and pregabalin.

\section{REFERENCES}

1. Pain terms: a list with definition and note on usage. Recommended by the IASP subcommittee on taxonomy. Pain. 1979;6(3):249.

2. Angst MS, Clark JD. Opioid-induced hyperalgesia: a qualitative systematic review. Anesthesiology. 2006;104(3):570-87.

3. Chu LF, Angst MS, Clark D. Opioid-induced hyperalgesia in humans: molecular mechanisms and clinical considerations. Clin J Pain. 2008;24(6):479-96.

4. Silverman SM. Opioid induced hyperalgesia: clinical implications for the pain practitioner. Pain Physician. 2009;12(3):679-84.

5. Mao J. Opioid-induced abnormal pain sensitivity: implications in clinical opioid therapy. Pain. 2002;100(3):213-7.

6. Vanderah TW, Ossipov MH, Lai J, Malan TP Jr, Porreca F. Mechanisms of opioid-induced pain and antinociceptive tolerance: descending facilitation and spinal dynorphin. Pain. 2001;92(1-2):5-9.
7. Reznikov I, Pud D, Eisenberg E. Oral opioid administration and hyperalgesia in patients with cancer or chronic nonmalignant pain. Br J Clin Pharmacol. 2005;60(3):311-8

8. Célèrier E, Rivat C, Jun Y, Laulin JP, Larcher A, Reynier P, et al. Long-lasting hyperalgesia induced by fentanyl in rats: preventive effect of ketamine. Anesthesiology. 2000;92(2):465-72.

9. Simonnet G, Rivat C. Opioid-induced hyperalgesia: abnormal or normal pain? Neuroreport. 2003;14(1):1-7.

10. Ossipov MH, Lai J, King T, Vanderah TW, Porreca F. Underlying mechanisms of pronociceptive consequences of prolonged morphine exposure. Biopolymers. 2005;80(2 3):319-24.

11. Gebhart GF. Descending modulation of pain. Neurosci Biobehav Rev. 2004;27(8):729-37.

12. Li Z, Li C, Yin P, Wang ZJ, Luo F. Inhibition of CaMKII $\alpha$ in the central nucleus of amygdala attenuates fentanyl-induced hyperalgesia in rats. J Pharmacol Exp Ther. 2016;359(1):82-9

13. Li Z, Yin P, Chen J, Jin S, Liu J, Luo F. CaMKII $\alpha$ may modulate fentanyl-induced hyperalgesia via a CeLC-PAG-RVM-spinal cord descending facilitative pain pathway in rats. PLoS One. 2017;12(5):e0177412.

14. Pergolizzi JV Jr, Raffa RB, Taylor R Jr, Rodriguez G, Nalamachu S, Langley P. A review of duloxetine $60 \mathrm{mg}$ once-daily dosing for the management of diabetic peripheral neuropathic pain, fibromyalgia, and chronic musculoskeletal pain due to chronic osteoarthritis pain and low back pain. Pain Pract. 2013;13(3):239-52.

15. Smith HS, Harris R, Clauw D. Fibromyalgia: an afferent processing disorder leading to a complex pain generalized syndrome. Pain Physician. 2011;14(2):E217-45.

16. Chappell AS, Ossanna MJ, Liu-Seifert H, Iyengar S, Skljarevski V, Li LC, et al. Duloxetine, a centrally acting analgesic, in the treatment of patients with osteoarthritis knee pain: a 13-week, randomized, placebo-controlled trial. Pain. 2009;146(3):253-60.

17. Dharmshaktu P, Tayal V, Kalra BS. Efficacy of antidepressants as analgesics: a review. J Clin Pharmacol. 2012;52(1):6-17.

18. Micó JA, Prieto R. Elucidating the mechanism of action of pregabalin: $\alpha(2) \delta$ as a therapeutic target in anxiety. CNS Drugs. 2012;26(8):637-48.

19. Bellato E, Marini E, Castoldi F, Barbasetti N, Mattei L, Bonasia DE, et al. Fibromyalgia syndrome: etiology, pathogenesis, diagnosis, and treatment. Pain Res Treat. 2012;2012:426130.

20. Crofford LJ, Rowbotham MC, Mease PJ, Russell IJ, Dworkin RH, Corbin AE, et al. Pregabalin for the treatment of fibromyalgia syndrome: results of a randomized, double-blind, placebo-controlled trial. Arthritis Rheum. 2005;52(4):1264-73.

21. Brennan TJ, Vandermeulen EP, Gebhart GF. Characterization of a rat model of incisional pain. Pain. 1996;64(3):493-501.

22. DuPen A, Shen D, Ersek M. Mechanisms of opioid-induced tolerance and hyperalgesia. Pain Manag Nurs. 2007;8(3):113-21.

23. Joly V, Richebe P, Guignard B, Fletcher D, Maurette P, Sessler DI, et al. Remifentanil-induced postoperative hyperalgesia and its prevention with small-dose ketamine. Anesthesiology. 2005;103(1):147-55.

24. Leal P da C, Clivatti J, Garcia JB, Sakata RK. Opioid-induced hyperalgesia (HIO). Rev Bras Anestesiol. 2010;60(6):639-47. English, Portuguese, Spanish.

25. Mixcoatl-Zecuatl T, Jolivalt CG. A spinal mechanism of action for duloxetine in a rat model of painful diabetic neuropathy. Br J Pharmacol. 2011;164(1):159-69.

26. Nakajima K, Obata H, Iriuchijima N, Saito $S$. An increase in spinal cord noradrenaline is a major contributor to the antihyperalgesic effect of antidepressants after peripheral nerve injury in the rat. Pain. 2012;153(5):990-7.

27. Andersen J, Stuhr-Hansen N, Zachariassen LG, Koldsø H, Schiøtt B, Strømgaard K, et al. Molecular basis for selective serotonin reuptake inhibition by the antidepressant agent fluoxetine (Prozac). Mol Pharmacol. 2014,85(5):703-14.

28. Iyengar S, Webster AA, Hemrick-Luecke SK, Xu JY, Simmons RM. Efficacy of duloxetine, a potent and balanced serotonin-norepinephrine reuptake inhibitor in persistent pain models in rats. J Pharmacol Exp Ther. 2004;311(2):576-84.

29. Mixcoatl-Zecuatl T, Jolivalt CG. A spinal mechanism of action for duloxetine in a rat model of painful diabetic neuropathy. Br J Pharmacol. 2011;164(1):159-69.

30. Obata H. Analgesic mechanisms of antidepressants for neuropathic pain. Int J Mol Sci. 2017;18(11): pii2483.

31. Cao Y, Wang H, Chiang CY, Dostrovsky JO, Sessle BJ. Pregabalin suppresses nociceptive behavior and central sensitization in a rat trigeminal neuropathic pain model. J Pain. 2013;14(2):193-204. 